J. Clin. Chem. Clin. Biochem.

Vol. 25, 1987, pp. 589-593

(C) 1987 Walter de Gruyter \& Co. Berlin - New York

\title{
Cystatin C, Alias Post- $\gamma$-Globulin: A Marker for Multiple Sclerosis?
}

\author{
By Francine Bollengier
}

Laboratorium Fysiopathologie van het Zenuwstelsel-Farmakologie, Vrije Universiteit Brussel, Brussels

(Received February 27/June 4, 1987)

Summary: Cystatin C, alias post- $\gamma$-globulin or $\gamma$-trace protein, has been shown to be a potent inhibitor of cysteine proteinases; this protein is normally present in different biological fluids, but particularly so in cerebrospinal fluid. The concentration of cystatin $\mathrm{C}$ was determined by radial immunodiffusion in cerebrospinal fluid from patients affected with multiple sclerosis, patients affected. with various neurological diseases and in controls; it was also determined in brain tissue from 2 patients affected with multiple sclerosis and 3 control brains. Cystatin $\mathrm{C}$ cerebrospinal fluid levels were undetectable or depressed in many multiple sclerosis cases and the median value differed significantly from the control one. Its low concentration in multiple sclerosis suggests that the regulation of cysteine proteinases is impaired in this disease; hence enhanced activity of cysteine proteinases could initiate, or increase the breakdown of myelin.

Although it is perhaps a little premature to consider cystatin $\mathrm{C}$ as a marker for multiple sclerosis, this protein is nevertheless associated to demyelination; consequently its biochemical assay in cerebrospinal fluid is recommended as a complementary diagnostic tool.

\section{Introduction}

Cystatin C, alias post- $\gamma$-globulin or $\gamma$-trace protein is a protein which is present in low concentration in human body fluids, especially in the cerebrospinal fluid (CSF) $(1,2,3)$. It has also been shown to be localized in the cytoplasma of cells, in the adenohypophysis (4), in the adrenal medulla (5) and in the A-cells of the Langerhans islets of the pancreas (6). The exact biological role of $\gamma$-trace protein is as yet unknown, but Löfberg \& Grubb (2) have proposed that it could be associated with the neuroendocrine system; recently Barrett et al. (7) have shown post- $\gamma$-globulin to be a potent inhibitor of the cysteine proteinases papain, ficin, and human cathepsins $B, H$, and $L$.

They proposed the name cystatin $\mathrm{C}$ for post- $\gamma$-globulin and suggested that its physiological function could well be the regulation of proteinase activity.

When routinely assaying CSF from patients with multiple sclerosis by agar gel electrophoresis, we fre- quently observed no cystatin $\mathrm{C}$ at all or very low relative values, in contrast to controls.

Using radial immunodiffusion, we investigated the cystatin C content of CSF from patients affected with multiple sclerosis, a group of patients with various neurological diseases and control CSF; we also determined cystatin $\mathrm{C}$ in brain specimens from 2 multiple sclerosis patients and 3 control brains.

The purpose was to confirm our earlier electrophoretic observations and to determine whether cystatin $\mathrm{C}$ can be considered as a marker for multiple sclerosis and demyelination.

\section{Materials and Methods}

Cerebrospinal fluids

- Control CSF were obtained from patients either without or with minor neurological signs, or minor psychotic disturbances $(n=25)$. These samples were considered normal by routine as well as by electrophoretic examination. Age range: $16-74$ years. 
- Patients affected with neurological diseases other than confirmed multiple sclerosis $(n=22)$ were selected on the basis of the clinical course of the disease, routine examination of the CSF and agar gel electrophoresis (tab. 1). Age range: 22-85 years.

- Patients affected with clinically confirmed multiple sclerosis $(n=31)$ were considered; the criteria used to establish the diagnosis were the following: clinical multifocal lesions of the CNS, the typical clinical evolution of the disease, routine examination of the CSF and agar gel electrophoresis. Age range: $14-72$ years.

No sex differentiation was made for any of the groups under investigation. All CSF samples were stored at $-20^{\circ} \mathrm{C}$ and thawed once; prior to assay by agar gel electrophoresis, CSF samples were concentrated on ultrafiltration membranes with a 10000 molecular weight cut off (Sartorius SM 145.39.025 N).

\section{Brain tissue}

Whole white and gray matter was obtained from patients with clinically confirmed multiple sclerosis; the diagnosis was established as for the CSF sample patients and confirmed by the presence of plaques in the post-mortem brain.

Multiple sclerosis brains were stored at $-70^{\circ} \mathrm{C}$ for several years (1-4 years) before extraction. Control brains were obtained from patients who were not affected with neurological diseases and whose brain appeared normal at dissection. Those brains were extracted immediately after autopsy.

For all brain specimens under investigation the delay between death and autopsy did not exceed $24 \mathrm{~h}$.

\section{Brain extraction}

The brain specimens ( $50 \% \mathrm{w} / \mathrm{v}$ homogenate) were homogenized in $0.01 \mathrm{~mol} / 1$ phosphate - $0.15 \mathrm{~mol} / 1 \mathrm{NaCl}-\mathrm{pH} 7.4$ and centrifuged at $20000 \mathrm{~min}^{-1}$. Supernatants were dialysed against distilled $\mathrm{H}_{2} \mathrm{O}$ at $4{ }^{\circ} \mathrm{C}$ and lyophilized.

\section{Assay procedure}

Post- $\gamma$-globulin (cystatin C) content was determined in single radial immunodiffusion using LC-Partigen post- $\gamma$-globulin plates (LC-Partigen post- $\gamma$-globulin product No. 7406 - Research list. Behringwerke AG. Marburg-Lahn. Hoechst AG). The post- $\gamma$-globulin plates were calibrated with protein standard human urine concentrate (product No. 7321. Research list. Behringwerke AG. Marburg-Lahn. Hoechst AG). CSF samples were assayed unconcentrated and the range of the assay procedure was $3.0-80.0 \mathrm{mg} / 1$.

\section{Statistics}

Since a normal distribution cannot be assumed in pathological states, the statistical method used to compare the different populations was the non parametric U-test of Wilcoxon ${ }^{1}$ ).

The existence or non-existence of correlations between the chosen variables was determined qualitatively by scatter diagrams as reported by Spiegel (8).

\section{Results}

Figure 1 shows the cystatin $\mathrm{C}$ contents of all groups under investigation. Controls gave a median value of $11.4 \mathrm{mg} / \mathrm{l}$ and a range of $4.6-31.2 \mathrm{mg} / \mathrm{l}$. The group of other neurological patients was characterized by some decreased cystatin $\mathrm{C}$ values, but on the whole the median value $(10.2 \mathrm{mg} / \mathrm{l})$ was very near the control one.

In the multiple sclerosis group many cystatin $C$ values were either zero or considerably decreased in comparison with the controls.

1) Documẹta Geigy - Tables scientifiques - Bạsel.

Tab. 1. CSF biochemical parameters and diagnosis of the neurological disorders other than multiple sclerosis.

\begin{tabular}{|c|c|c|c|}
\hline $\begin{array}{l}\text { Patients } \\
(n=22)\end{array}$ & $\begin{array}{l}\text { Total protein CSF } \\
(\mathrm{g} / \mathrm{l})\end{array}$ & IgG profile in agar gel electrophoresis & Diagnosis \\
\hline 1 & 0.50 & increased oligoclonal IgG & uncertain \\
\hline 2 & 1.61 & tendency towards oligoclonal IgG & encephalitis \\
\hline 3 & 0.51 & increased oligoclonal IgG & neurosyphilis \\
\hline 4 & 2.27 & increased oligoclonal IgG & meningitis \\
\hline 5 & 0.39 & no oligoclonal IgG & cervical myelopathy \\
\hline 6 & 1.20 & no oligoclonal IgG & Guillain-Barré syndrome \\
\hline 7 & 0.53 & no oligoclonal IgG & Guillain-Barré syndrome \\
\hline 8 & 0.86 & no oligoclonal IgG & myelitis \\
\hline 9 & 0.23 & oligoclonal IgG & neurosyphilis \\
\hline 10 & 0.44 & slightly increased oligoclōnal IgG & parasitosis \\
\hline 11 & 0.54 & increased oligoclonal IgG & neurosyphilis \\
\hline 12 & 1.80 & oligoclonal IgG & undetermined \\
\hline 13 & 1.08 & increased oligoclonal IgG & encephalitis \\
\hline 14 & 0.84 & no oligoclonal IgG & polyneuropathy \\
\hline 15 & 0.75 & increased oligoclonal IgG & encephalomyelitis \\
\hline 16 & 0.84 & oligoclonal IgG & uncertain \\
\hline 17 & 0.48 & increased oligoclonal IgG & congenital șyphilis \\
\hline 18 & 0.46 & no oligoclonal IgG & cervical myelopathy \\
\hline 19 & 0.43 & oligoclonal IgG & medullary compression \\
\hline 20 & n.d. & oligoclonal IgG & undetermined \\
\hline 21 & n.d. & increased oligoclonal IgG & meningitis \\
\hline 22 & 0.35 & oligoclonal IgG & parasitosis \\
\hline
\end{tabular}




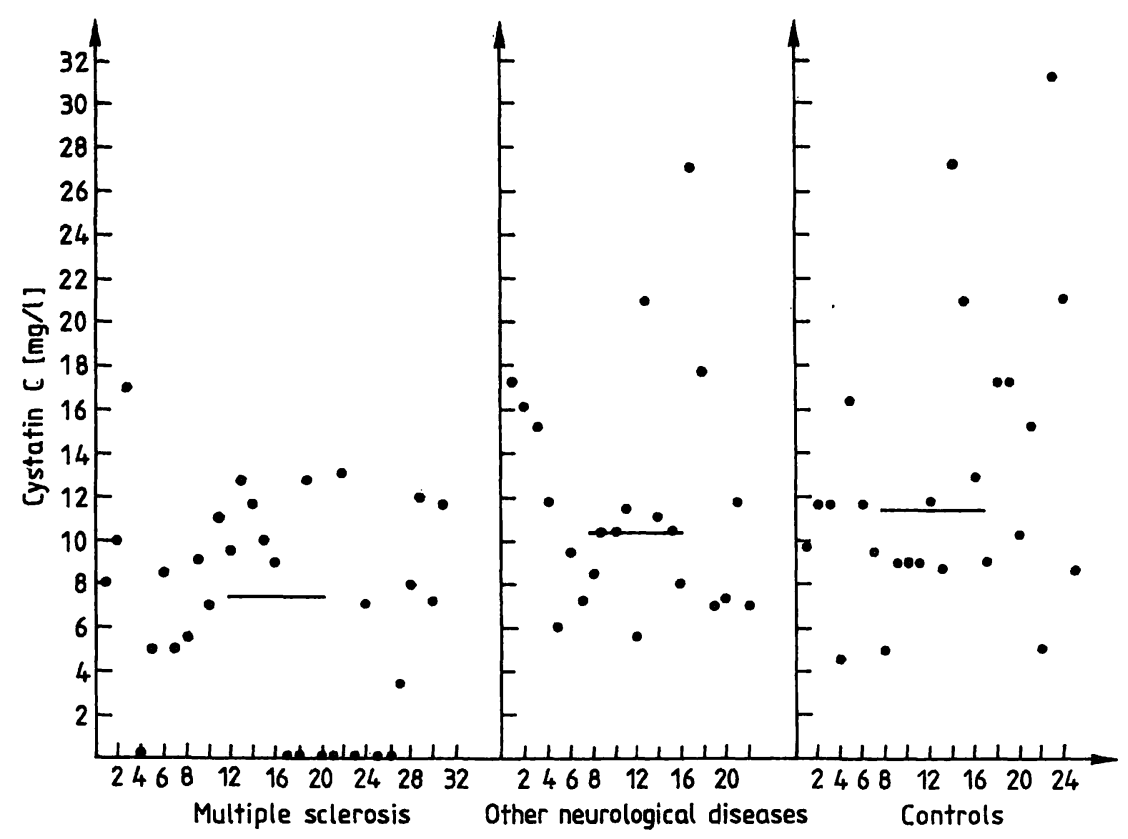

Fig. 1. Cystatin $C$ values in patients affected with multiple sclerosis $(n=31)$, patients affected with other neurological diseases $(n=22)$ and controls $(n=25)$.

$\longrightarrow=$ median

The median values and significant differences between the control group and pathological groups are reported in table 2 .

Tab. 2. Median values and significant differences between controls and pathological samples.

\begin{tabular}{|c|c|c|}
\hline & $\mathbf{n}$ & $\begin{array}{l}\text { Cystatin C } \\
\text { (mg/l) } \\
\text { Median }\end{array}$ \\
\hline $\begin{array}{l}\text { Controls } \\
\text { Multiple sclerosis } \\
\text { Patients with other neurological diseases }\end{array}$ & $\begin{array}{l}25 \\
31 \\
22\end{array}$ & $\begin{array}{l}11.4 \\
\left.\left.7.2^{*}\right)^{\circ}\right) \\
10.2\end{array}$ \\
\hline
\end{tabular}

*) Multiple sclerosis values differ from controls for $2 \alpha=0.01$

-) Multiple sclerosis values differ from other neurological diseases values for $2 \alpha=0.02$

$\mathbf{n}=$ number of cases
Multiple sclerosis differs significantly from controls and other neurological diseases, but there are no significant differences between controls and other neurological diseases.

A possible correlation between the age of the patients and the cystatin $C$ content was investigated but none could be established.

When assaying brain specimens at the total protein concentration of $0.3 \mathrm{~g} / \mathrm{l}$ (CSF mean value) no cystatin $\mathrm{C}$ could be detected; it was necessary to concentrate the brain specimens up to a total protein concentration of $50.0 \mathrm{~g} / 1$ to obtain a position answer (tab. 3). This means that the cystatin $C$ levels of both normal and pathologic brains are exceedingly low, and consequently hardly detectable, as is the case for serum.

Tab. 3. Cystatin $C$ values in brain extracts from patients affected with multiple sclerosis and from controls.

\begin{tabular}{llll}
\hline & $\begin{array}{l}\text { Brain extracts } \\
(\text { total protein content: }\end{array}$ & & $\begin{array}{l}\text { Brain extracts } \\
\text { (total protein content: } \\
\end{array}$ \\
& $\begin{array}{l}0.3 \mathrm{~g} / \mathrm{l}) \\
(\mathrm{mg} / \mathrm{l})\end{array}$ & & $\begin{array}{l}50.0 \mathrm{~g} / \mathrm{l}) \\
(\mathrm{mg} / \mathrm{l})\end{array}$ \\
\hline White matter MS 1 & - & White matter MS 1 & 5.0 \\
Gray matter MS 1 & - & Gray matter MS 1 & 7.8 \\
White matter MS 2 & - & White matter MS 2 & - \\
Gray matter MS 2 & - & Gray matter MS 2 & 2.4 \\
White matter control 1 & - & White matter control 1 & 4.0 \\
Gray matter control 1 & - & Gray matter control 1 & 4.0 \\
White matter control 2 & - & White matter control 2 & 7.8 \\
Gray mätter control 2 & - & Gray matter control 2 & 8.0 \\
White matter control 3 & - & White matter control 3 & 10.8 \\
Gray matter control 3 & Gray matter control 3 & 11.8 \\
\hline
\end{tabular}

MS = multiple sclerosis 


\section{Discussion}

In 1965 Mac Pherson (9) first reported a quantitative estimation of cystatin C, formerly post- $\gamma$-globulin, in normal and pathological CSF. She found a general decrease of cystatin $C$ in patients affected with multiple sclerosis; this finding was confirmed by Pepe et al. (10). Löfberg et al. (11) however, found no significant decrease in the concentration of $\gamma$-trace in CSF in the multiple sclerosis group. As a general rule they observed that the concentration of $\gamma$-trace in CSF was slightly increased in individuals older than 60 years.

In contrast to Löfberg et al., but in agreement with Mac Pherson, we found a significant decrease of $\gamma-$ trace in the multiple sclerosis group, when we investigated numerically much larger groups. For multiple sclerosis patients and neurological patients with disorders other than multiple sclerosis, Mac Pherson reported mean values of $7.1 \mathrm{mg} / \mathrm{l}$ and $9.8 \mathrm{mg} / 1$, respectively, whereas we found median values of $7.2 \mathrm{mg} / \mathrm{l}$ and $10.2 \mathrm{mg} / \mathrm{l}$. Contrary to earlier findings (11), no correlation was found between patient age and the cystatin $\mathrm{C}$ content.

The primary site of cystatin $C$ is not known with certainty, due to the wide organ distribution of the protein.

According to Mac Pherson (9) transsudation of cystatin C from the blood to the CSF is to be excluded, since there are rarely detectable levels in normal human serum, compared with CSF. It is a fact that cystatin $\mathrm{C}$ concentrations are much higher in CSF than in serum (3): when we concentrated serum 20 times, cystatin $\mathrm{C}$ could still not be detected by radial immunodiffusion, whereas the technique works very well for unconcentrated CSF.

Hochwald et al. (12) demonstrated in monkeys that many tissues incorporate labeled amino acids into cystatin $C$; submaxillary gland seemed to be the most active; brain cultures were negative, but the choroid plexus did produce some degree of cystatin labelling. From their study they derived the hypothesis that this protein is transported to the CSF by blood. However since the choroid plexus produces a large part of the CSF, this could be a likely source of cystatin $\mathrm{C}$.

Our determined cystatin $\mathrm{C}$ contents in human brain material (tab. 3) do not support the notion that this protein is produced in the CNS. Consequently the cystatin $\mathrm{C}$ of the CSF cannot be derived from brain cystatin $\mathrm{C}$; it seems more likely that cystatin $\mathrm{C}$ diffuses from the CSF to the CNS in very small amounts. But it is difficult to consider these results * as significant, since the brain specimens had to be "super-concentrated," in order to find any positive results at all.

Abnormal cystatin $C$ levels are interesting in view of the possible biological role of this protein. Given that this protein has been found in many tissues, but in very low concentrations in normal serum, it could be that cystatin $C$ is an intracellular inhibitor of cysteine proteinases. Since cysteine proteinases are abundant in the body and are responsible for much of the intracellular proteolysis (13), the role of cystatins could be vital in limiting proteolysis. At least one type of cystatin, namely from chicken egg white, has been demonstrated to be an inhibitor of cysteine proteinases (14).

Recently, studies have been reported on human cystatin from the serum of patients affected with autoimmune diseases (15). From the biochemical data (relative molecular mass, amino acid composition, amino acid sequence, isoelectric focusing) it was concluded that this protein was practically identical to human post- $\gamma$-globulin, a protein of hitherto unknown function.

Barrett et al. (7), as mentioned above, suggested that the physiological role of this protein may well be the local regulation of cysteine proteinases, which pass from the lysosomal system to extracellular fluid, and also to the cytoplasm in some cells. Indeed, many cathepsins are associated with lysosomal like particles and are believed to participate in mechanisms of protein breakdown or are released into the cytoplasm to participate in the turnover of cellular components. If demyelination is caused by one or more intracellular proteases, then inhibition of these enzyme activities could offer the possibility of limiting the extent of demyelination. In multiple sclerosis the regulation of cysteine proteinases seems to be impaired; indeed most cystatin $C$ values in CSF were either zero or depressed.

\section{One may speculate}

1. that the very low inhibition levels in the CSF of multiple sclerosis patients are due to a decreased release of inhibitor from cells, which in turn is a result of the underlying immunological process in this disease; and

2. that the activity of the CSF may make a significant contribution to pathological processes, such as demyelination, which occur in the CNS.

Another mechanism could be the role of macrophages during the effector phase of demyelination. Because of the predominance of macrophages in lesions of inflammatory demyelinating diseases such as multiple 
sclerosis, it has been suggested that such cells may be involved in degradation of myelin; indeed, degradation of basic protein in myelin by neutral proteases secreted by stimulated macrophages has been demonstrated by Cammer et al. (16).

Certain cysteine proteinases (for example cathepsin B) are synthesized by macrophages and the balance between inhibited cysteine proteinase-associated macrophages and active cysteine proteinase-associated macrophages is most probably impaired by the decrease of cystatin $\mathrm{C}$; this impaired balance may induce demyelination.

\section{References}

1. Colle, A., Guimet, R., Leclercq, M. \& Manuel, J. (1976) Clin. Chim. Acta 67, 93-97.

2. Löfberg, H. \& Grubb, A. O. (1979) Scand. J. Clin. Lab. Invest. 39, 619-626.

3. Poulik, M. D., Perry, D. J., Vokac, E. \& Sekine, T. (1983) Clin. Chim. Acta 128, 245-260.

4. Grubb, A. \& Löfberg, H. (1982) Proc. Natl. Acad. Sci. USA 79, 3024-3027.

5. Löfberg, H., Nilsson, K. E., Strömblad, L. G., Lasson, A. \& Olsson, S. O. (1982) Acta Endocrinol. 100, 595- 598.

6. Löfberg, H., Strömblad, L. G., Grubb, A. O. \& Olsson, S. O. (1981 b) Biomed. Res. 2, 527-535.

7. Barrett, A. J., Davies, M. E. \& Grubb, A. (1984) Biochem. Biophys. Res. Commun. 120, 631-636.

8. Spiegel, M. R. (1972) Schaum's outline of theory and problems of statistics, pp. $241-242$, The Graw-Hill International Book Company, New York.
The absence or low level of cystatin $C$ is especially marked in multiple sclerosis, an inflammatory demyelinating disease. In the non demyelinating inflammatory diseases in the patients group with other neurological diseases (tab. 1, fig. 1) it is obvious that the cystatin $\mathrm{C}$ values score mainly in the control range.

Consequently, although it is perhaps a little premature to consider cystatin $\mathrm{C}$ as a marker for multiple sclerosis, this protein is nevertheless associated with demyelination.

In our opinion its routine biochemical assay can be considered as a complementary diagnostic tool.

9. Mac Pherson, C. F. C. (1965) Clin. Chim. Acta 11, 298309.

10. Pepe, A. J. \& Hochwald, G. M. (1967) Proc. Soc. Exp. Biol. Med. 126, 630-633.

11. Löfberg, H., Grubb, A. O., Sveger, T. \& Olsson, J. E. (1980) J. Neurol. 223, 159-170.

12. Hochwald, G. M., Pepe, A. J. \& Thorbecke, G. J. (1967) Proc. Soc. Exp. Biol. Med. 124, $961-966$.

13. Kirschke, H., Langner, J., Riemann, S., Wiederanders, B., Ansorge, S. \& Bohley, P. (1980) Ciba Found. Symp. 75, $15-35$.

14. Anastasi, A., Brown, M. A., Kembhair, A. A., Niaklin, M. J. H., Sayers, C. A., Sunter, D. C. \& Barrett, A. J. (1983) Biochem. J. 211, 129-138.

15. Brzin, J., Popovic, T. \& Turk, V. (1984) Biochem. Biophys. Res. Commun. 118, 103-109.

16. Cammer, W., Bloom, B. R., Norton, W. T. \& Gordon, S. (1978) Proc. Natl. Acad. Sci. USA 75, 1554-1558.
Dr. Francine Bollengier Laboratorium Fysiopathologie van het Zenuwstelsel-Farmakologie Vrije Universiteit Brussel Laarbeeklaan 103 B-1090 Brussel 
